\title{
1. Introduction to Governance Analysis: Critical Enquiry at the Intersection of Politics, Policy and Society
}

\section{Emma Carmel}

\section{INTRODUCTION}

This book offers a theoretical and analytical account of governance that enables us to investigate how societies are governed, and with what consequences for power and inequality. This approach enables us to treat governance as at once fully political and fully social, and to rescue its relevance for the analysis of politics, policy and society.

How we are governed is vital in the reproduction and transformation of societies. The ideas, decisions and actions that govern our collective life have material and discursive effects that structure social relations. And because such effects can be contested or erased over time, we need a theoretical account of governing that enables us to make visible the politics of these structuring effects in different settings. Our account of governance is therefore concerned both with the material and discursive manifestations of power and their contestation (the political), and also with how social formations are structured, (self-) organised and managed over time (the social).

In this book, we conceptualise governance as regime(s) of governing practices that produce socio-political orders, of varying durability and contingency. We treat governance as produced by the material actions, interpretive understandings and structured social positions of socially constituted political actors. We move beyond poststructuralist accounts of government and discourse, and beyond accounts of state-centred policymaking. As such, our account is self-consciously 'post'-poststructuralist. We use this term as a shorthand to acknowledge the influence of original writings on governmentality, semiosis and state theories that we combine with a resolutely historicist and actor-centred approach. The actor-centredness of our conceptualisation gives due emphasis to meaning, action and structure in shaping governance in different settings. Any theoretical account is of course always developed in dialogue 
with existing theorists. We combine the significant insights from poststructuralist writings on government, governmentality, state and hegemony, with the actor-centred and materialist pre-occupations of political anthropology and institutional ethnography. I draw on these approaches in Chapter 2, to explain the three central conceptual features of our account of governance: regimes, governing practices, and the production of socio-political order.

In addition, we have developed this account with the intention of examining how governing is done, and how and why it matters in particular places and at particular times. This means that we are centrally concerned with empirical investigation. In light of this aim, the book also outlines an analytical framework that enables us to apply our theoretical account to explain specific empirical cases of governance. This is set out in Chapter 3. This approach provides an analytical toolkit to identify how particular instances of governance structure, and are structured by, the relations between political actors; the processes and practices they adopt to meet their goals; and the wider contexts of their action. Our framework offers a holistic investigative lens to examine and explain the relationships among actors, structures and processes, and their implications for the production of socio-political order in specific contexts.

In this opening chapter, I examine the conceptualisations of 'governance' that were developed from the 1990s to the 2000s. These all emphasised the importance of complexity and unpredictability in shaping public policy. They addressed what were generally viewed as the significant contemporary changes in the state, politics and political economy, under conditions of globalisation and marketisation. I discuss the key characteristics of debates that centred around the idea that this period saw the emergence of something new, called governance. I examine some critiques, and consider the importance of the context(s) within which they were developed, in order to explore their limitations in making sense of public policy and how it is made. As Davies and Chorianopoulos (2018) rather witheringly suggest, by the $2010 \mathrm{~s}$, these debates had become rather sterile. The shortcomings of discussions about the end of the state; new 'types' of state, new 'modes' of governing, and the emergence of, and potential for, new 'types' of 'democratic' governing were increasingly evident. The assumptions that such debates rested on were shown to be normatively misplaced as well as ahistorical, seduced by a myopic and teleogical view of contemporary political and social change.

In this chapter, I mark out where our differences lie in relation to these earlier debates. I do so in order to suggest that we might usefully rescue the theoretical relevance of governance as a term, by proposing a conceptualisation that meets certain requirements. The first requirement is a conceptualisation that accommodates the need for a theoretically coherent account of governing, rather than a description of an empirical phenomenon, like the decline, congestion or transformation of the state. Our second requirement is that this account must 
facilitate an interrogation of, rather than rest on, assumptions about how states, statehood and governing are related, both in general, and in specific contexts. Both these requirements are addressed in Chapter 2. Third, this theoretical account should be both historicised and also analytically coherent across contexts. Analytical coherence refers to the ability to apply our account to specific but diverse cases of 'governance' and governing. I address this in Chapter 3 by discussing our analytical framework, which can be applied in a range of contexts to explore how specific, contextualised instances of governing unfold and exert their effects. In Chapters 4 to 10 , we offer seven case studies of governance, ranging from local to comparative and European contexts, and covering an array of public policy issues. Each contribution addresses its independent research questions, situated in theoretical debates about governance and policy in its particular policy area. Each contribution also reflects on how governance analysis provided a way of looking, a framework for organising, or insights into the implications of governing, for these empirical cases. Taken together, these contributions enable us to show how governing is done: undertaken by political actors, who act purposefully, interpret their actions, and contingently respond to circumstance and environment. And, at the same time, we also show with what implications governing is done across these cases: how these circumstances and environments are themselves structured by, and structure, existing relations of power, authority and resources.

Before we introduce these contributions in more detail, however, this chapter starts by problematising our understandings of public policy and policymaking as a task of government or as an attribute of statehood. This discussion about policy provides an analytical 'way in' to review afresh the debates on 'governance' of recent decades, presented in the subsequent section. I use these reviews of 'policy' and of 'governance' studies to highlight and contextualise the themes and concerns that underpin the presentation of our theoretical account of governance in Chapter 2, and of governance analysis as an approach to studying public policy and governing in Chapter 3.

\section{'POLICY' STUCK BETWEEN POLITICS, POLICYMAKING AND STATE INSTITUTIONS}

The most common way that 'policy' features as a conceptual object of analysis is in studies of policymaking processes. There are numerous mid-level theories of public policy focused on processes of policymaking (e.g. Baumgartner and Jones, 2010[1993]; Kingdon, 1984; Sabatier and Jenkins-Smith, 1993). Some of these have proved very efficacious in explaining the relative success or failure of specific social or economic interests in pursuing these interests in policymaking. They continue to inspire critical development work on policymaking and processes (Cairney and Jones, 2016). For the analyst interested 
in how policy might relate to governing, however, such approaches to policy have a peculiarly antisceptic quality, driven by a decisionist view of policymaking. While apparently explaining how interests and ideas shape policy, 'policy' itself is presented ontologically as a decision or output. The politics of the purpose, practice and outcomes of policy is rather presented as epiphenomenal to the story. As such, policy is reified as an object, a thing produced by a state as the outcome of competitive interests in largely instrumentalist and technocratically conceived policy processes. What is contested in these studies is the characteristics of the process: both the state and policy remain unexamined, even when the messy business of practical policymaking are directly addressed (Weible and Cairney, 2018).

From within political science, Rod Rhodes and David Marsh (1992a, 1992b) and Martin Smith (1993) were leading scholars in the development of a complex institutionalist understanding of how policy is shaped and its articulation with institutions of the state. Within a neo-pluralist paradigm, these authors asserted the importance of treating the state as a disaggregated but co-ordinated set of institutional arrangements. It was argued that state action in different policy areas was subject to societal interests, of varying organisational coherence and power, that self-organised in a loosely co-ordinated way to shape policy outputs and even future institutional arrangements. The form and degree of co-ordination around particular policy concerns varied, and was categorised as a range of network types. For example, long-term, close-knit groups of organised economic interests engaged with specialist state actors having shared norms and values, produced 'policy communities', seen typically in agriculture (farmers, agri-business, agri-chemicals and technical specialists in ministries). More loosely based, highly differentiated groups might temporarily assemble over a specific cause (protecting woodland from privatisation). Nonetheless, analysis of policy communities, networks and coalitions assume the state is a centripetal locus of political power around which social and economic interests coalesce. In line with its disciplinary origins in political science, these theories of policymaking did not engage with wider sociological theories of states and statehood and their transformation (Foucault, 2007; Jessop, 1990) until much later. The ontology of policy was unquestioned and even tautologically defined: policy was what was produced in policy processes.

Earlier work in organisational sociology, however, already offered a wider perspective, in which the production of policy was not reducible to questions of interest, organisational capacity and conscious action around governments and legislation (Cohen et al., 1972; Lindblom, 1979). These studies showed that policy emerged from institutions that themselves shaped the identification of interests, and that interests could be invoked and reproduced with varying degrees of purpose and consciousness by social actors. The latter had gained 
particular expression in the contribution of Bachrach and Baratz (1962) and their work on the mobilisation of bias as a structural feature of policymaking, in which 'non-decisions' and decisions not to act in policy matter just as much as decisions made and legislation passed. In this vein, with an even stronger actor orientation, Lipsky's (2010) work on 'street-level bureaucrats', first published in 1980, has been a fruitful resource for scholars working on how policy works in practice. He showed that policies do not (only) comprise legislation, regulations and the distribution of resources as assumed in work on the high (state) politics of policymaking. Citizens and service users experience policy as it is directly made by practices of street-level bureaucrats who adjust their behaviour to accommodate their own preferences, norms, expectations and habits. Policy is made, unmade and re-made in actions on the ground that might mediate, contradict or harden policy goals and intent of 'policymakers'. Lipsky's insights enabled scholars to explore how policy takes effect for citizens on the ground, and highlighted that policy is 'peopled', that is, it is produced by people as social actors in concrete contexts, not only abstractly produced as formal rules and regulations.

So prior to the emergence of 'governance' literatures in political science, public administration and political economy, scholars from these disciplines, concerned with policy (rather than 'the state' per se) were already interrogating and problematising how states and organisations contribute to making public policy over time. Still, this work shared some assumptions: 'government' makes policy decisions; leads the complex institutions that comprise the state; and is (should be) accountable for the implementation of those decisions. Furthermore each of these approaches in their different ways remained intently focused on processes of policymaking, rather than on policy per se. 'Policy' in analyses of processes is generally a vehicle for examining interests and values of political actors. Implementation is concerned with the distance between policy intent and policy outcome (and how these can be measured or overcome).

Analysts working in specific policy domains, in contrast, problematise 'policy', and see policy as produced dynamically in specific contexts and settings, whether this is in environmental, criminal justice, migration or education policy, for example. Researchers with interest in these fields, rather than in policy per se, seek to address the purposes, politics, ethics, appropriateness and meaning of policy in those contexts. They show that some of the most important questions about policy are only tangentially addressed in 'policy studies':

- What is the problem addressed by; what are the rationales for, and purpose of, specific public policies?

- How is the problem, rationale and purpose related to power relations and contexts of the field, including knowledge of that field? 
- What other aspects of the organisation of societies are addressed, disguised, erased in this policy?

- How does practice of policy change its purpose, shape the rationale, and address or alter the power relations in the field?

In this book, it is these questions that we link to wider concerns of how governing is done, by whom and with what effects. They lead us to questions about relationships between ideas about 'the state', governing, policy and society. They highlight the uncertain ontology of 'policy' as an instrument of government and state, and the constitution of policy-in-practice and how it takes effect, in ways rather more complex than can be easily accommodated in studies of policy processes.

In our account of governance, we use the terms policy and public policy interchangeably. The term 'public' in this context signals the collective and social aspects of governing. We treat policy as involving the purposeful use of one's own and others' resources (money, people, power) for achievement of these collectively applicable goals to shape the actions of others. Policies generate new - or confirm existing - inequalities of power that affect two aspects of public policymaking. First, this concerns who is subject to which aspects of public policy (laws, regulations, access to resources or services) and under what conditions. Second, it also concerns who has access to decision-making in which arenas that shape diverse aspects of public policy. The emphasis on steering social subjects that underpinned many subsequent analyses of policy and political action, discussed next, also appears in our account of governance presented in Chapter 2.

However, we go much further in our elaboration of the political and social implications of steering social subjects in unequally structured regimes of governance. Governing attempts to shape social subjects and their relational positions of power, as well as steering their action. As such, 'policy' comprises both purpose and practice. 'Policy' is an aspect of governing practices that contributes to the creation and reproduction of governance regimes over time, but the specific relationship of policy to states and to governing in any one case is a matter for empirical investigation rather than theoretical assumption.

\section{'GOVERNANCE' STUCK BETWEEN STATE STEERING AND NEO-LIBERAL HEGEMONY}

In the meantime, the context within which all these ideas about policy processes were developed was changing rapidly. Party politics since the Second World War in 'developed', Western, liberal countries was seen as becoming dynamic and less predictable, while the global policymaking environment became more multi-layered and constraining for such states. Significant con- 
tributors to interpreting these developments were the democratic 'overload thesis' and related arguments. These arguments suggested that states could not manage either the financial or the political demands placed upon them, as providers of employment, economic growth and prosperity, distribution and welfare in the expanding post-war state (see discussion in Birch, 1984).

These contentions were further promoted and given legitimacy by the emergence of informal economic governance including (originally) the influential Tri-lateral Commission that was followed by the Organisation for Economic Co-operation and Development (OECD), and later by formal trade arrangements and other mechanisms of economic governance (Ansell and Torfing, 2016, pp. 6-7). New constraints of integration in a globalising political economy were uneven, but nonetheless significant for states, individuals and social groups (Bakker, 2008; Rosenau, 2000; Sassen, 1996). Increasingly powerful international financial institutions in the postcolonial and post-Cold War period took up the role of trying to exert their authority over global economic development, cast in a mould of minimalist social protection and the normalisation of monetarist economics. Taken together these developments shaped the development of legal norms, the perceived possibilities of political action, and trajectories of political economy in transnational, national and local policy spaces (e.g. Gill and Cutler, 2014; Shaffer, 2013).

On the one hand, there was a significant divestment of public assets to private ownership, including land, buildings, industries, infrastructure and financial resources (pensions most notably) in Western and in postcolonial states, later in former Warsaw Pact countries. On the other hand, this exclusion of the state from formerly public/collectively organised policies and services was frequently also combined with the inclusion of private actors in the organisation, delivery and management of many assets that remained publicly owned, like social benefits, and services for unemployment, water, education. These developments did not 'emerge'. They were political and purposeful decisions to divest, privatise and marketise (Broad, 2006; Prince, 2012; Saint-Martin, 1998; Seabrooke and Tsingou, 2009; Wedel, 1998). Yet the capacity of the (developed, Western, liberal) state to deal with these developments - that were presented as structural conditions - was questioned across a whole range of policy domains (see, among many other examples, Botzem and Hofmann, 2010; Newman, 2004; Ponte and Cheyns, 2013). The boundaries of policy, politics and the characteristics of statehood were challenged by perceptions of threats to the presumed social, economic and territorial integrity of post-war states (Jessop, 1999, 2002). 


\section{Governance and Steering from Markets to Partnerships}

Contributing to this sense of change, internally, the roles of the state in Western Europe were seen as more diverse (states were 'doing more things') and, at the same time, these societies were changing rapidly. Interpreting these sociological developments, another group of authors suggested that 'looking to the state' for the pursuit of collective goals and collective action had become a forlorn and even a foolish task:

[in] contemporary society no single actor, public or private, has the knowledge and capacity to solve complex, dynamic and diversified problems (Kooiman, 1993, p. 4; also 2003, pp. 57-60, 196-208).

Yet even accepting this premise, the challenge of how to organise 'the process of steering society and the economy through collective action in accordance with common goals' (Ansell and Torfing, 2016, p. 4) still remained. From this position, then, emerged both prescriptive and descriptive arguments, that public policy as a state activity was now more about 'steering' rather than 'rowing'. Mayntz (2016, p. 260), reviewing decades of theorising about steering (including her own foundational work), suggests it comprises four elements:

(1) a steering subject, typically the government, the state or some public authority,

(2) steering instruments, in particular law, (3) a policy goal and (4) the target group or object of steering ... Steering presupposes the political intention to direct a specific social process or effect a specific change in the economy or civil society, but the concept does not imply that the goal of intervention is in fact achieved.

Steering was a way of describing what policy was for and how states or 'public authorities' asserted purposeful action in the process of shaping the actions of others. The emphasis on 'steering' complex societies created new roles for public policy, and led to new ideas about the role of policymakers in the state. In particular, Rod Rhodes (e.g. 1996, 2000), developing his earlier work on different types of networks, argued that the increasingly accepted sceptical position about the role of the state and state policymakers resulted in major shifts in the organisation of decision-making within the UK (one of the most centralised 'Western' states), creating a 'hollowed-out state'. Later attempts to describe empirical shifts in how policy, politics and the institutional characteristics of states were organised and related were dominated by Bevir and Rhodes' contention that there were alternative narratives of governance, later discussed as 'three waves of governance' (Bevir, 2003; Rhodes, 2012); see also the discussion in Kjær (2011). 
In a first 'wave' of governance/policymaking shifts, the adoption of market-based principles for the organisation and delivery of policies became commonplace, and public policymakers became subject to new management and control mechanisms. Such contract-based systems for organising public policy must be monitored in terms of whether they meet immediate policy goals for which they were designed, and also whether they meet wider policy and political purposes. In the face of new contract-based ways of thinking about policymaking and delivery, combined with devolution to agencies, the risk of policy fragmentation and incoherence was significant. The need for oversight of policy developments came under scrutiny by policymakers and analysts. For example, how does one policy, subject to a specific contract with targeted aims, affect policies or social groups in related policy areas? Who has oversight of this interaction? The risk of 'governance failure' (Jessop, 2003) was acute.

To manage and improve state oversight over policy fragmentation, 'co-ordination' and 'regulation' strategies were developed, in a 'second wave' of governance. This second wave, argues Rhodes (2012) introduced the importance of partnerships, and public-public institutional alliances, focused on achieving specific policy or service outputs, oriented as mechanisms to generate state and political capacity across a range of places, political contexts and policy areas (e.g. Bode, 2006; Chesterman and Fisher, 2009; Osborne, 2010; Sabel and Zeitlin, 2010; Schuppert, 2011). These types of co-ordination arrangements could be formal, involving state sanction, requirements and regulation. Or they might be informal, or semi-formal arrangements with varying degrees of institutionalisation (Beermann, 2017; Liese and Beisheim, 2011; Mörth, 2009; Raffaele, 2017)

Contrary to the claim that this constituted a new wave or alternative mode of governance for 'the state', co-ordination strategies can rather be seen as enhancing existing trajectories in policymaking. In an elaboration of marketised governing practices, the diversity of institutional partnerships expanded across scales and between policy domains; informal partnerships co-existed with contractualised policy delivery; and policy coherence and sustainability were subject to temporal limitations, as delivery and practice was organised around contracts for projects, pilots and 'experimental government'. In a similar vein, and still focused on the 'developed state', while seeking to describe changing empirical phenomena, Newman (2005) and Newman and Clarke (2009) identified more complex, layered and co-existing 'modes' of governance, where what went before (hierarchical, direct state-directed bureaucratically organised policymaking) is layered with both marketised, contractualised policymaking and also informal, self-organised 'modes' of governance in networks. Taken together, these empirical developments were 
interpreted as intensifying and extending the highly structured opacity, complexity and contingency of government from the 1990s onwards.

There is a more significant problem for the story about successive waves of governance shifts, however. In postcolonial contexts, both the adoption of market-based principles, and the initiation and monitoring of regulatory control, especially by international organisations promoting 'good governance' in the liberal tradition, were not successive 'waves', but part and parcel of the same process. This dual process deliberately re-worked colonial distributions of power, authority and interests. It did so in contexts that were national and regional, but also transnational, neo-liberal and 'Western'-dominated (Mignolo, 2010), sustained by continued universalisation of 'Western' understandings and experiences of national statehood, politics and power (de Sousa Santos, 2012; Mignolo, 2007, 2011). This re-working transformed the anti-imperial conflicts over power resources, autonomy and control in the marketised and globalised historical contexts of the postcolonial period, but it did not resolve them (Elgert, 2010; Escobar, 2001; Gupta, 1995; Kothari, 2005). This complex re-working further accelerated, extended and intensified after the end of the Cold War and the loss of Soviet spheres of influence in a number of postcolonial contexts.

Thus, rather than being new developments of complex and opaque governance, in the 'Global South', also later in Eastern Europe and central Asia, the politics of policymaking and the assertion of domestic interests continued to be in politically complex and financially constrained circumstances, subject to their own dynamics (Aitken, 2010; Berry and Gabay, 2009; Bridge and Wood, 2005; Larner and Laurie, 2010; Stattman and Gupta, 2015; Vaughan and Rafanell, 2012). Postcolonial domestic policy actors moved between, endorsed and/or contested marketisation agendas and the imposition of financial, political and social controls in a wide array of settings as a matter of course. These included structural adjustment programmes; trade negotiations; donor-funded health and social programmes; and development and governance loan conditionality. They did so across transnational, national and local scales and spaces, both governmental and non-governmental.

So, some specific types of contractualised and partnership governing practices described as 'new' may indeed have been relatively novel, across the globe. However, complexity of state and public authority, opacity of power relations, and contingency in governing are historically quite 'normal'. Implicitly referencing Western developed states, but making universalised conceptual claims, the narratives of governance change morphed into theoretical claims that significantly misinterpreted the universalised characteristics, coherence and integrity of states and government both in the post-Second World War period and earlier (see Chapter 2). They also misrepresented this ahistorical view of states and policymaking as a referential norm from which 
the emergence of complex co-existing forms of governance appeared to be an aberration (Bevir, 2010).

Furthermore, the empirical shifts and trajectories described in these literatures are not evident to the same degree in all states. They are not even evident to the same degree in all policy areas in individual states. The governing practices described in these literatures represent empirical trends or trajectories, traces of which can be seen in a range of settings, from local authorities (see Harlock, Chapter 7; Morgan-Trimmer, Chapter 9) to projects of regional integration (see Kan, Chapter 10). Their theoretical status as a new form of politics, policy or statehood is not convincing, as we discuss next.

There were three significant theoretical responses to these developments that we discuss in the next section. Starting from around the early 2000 s, the 'Roskilde school' used the concept of 'network governance' to make normative prescriptions regarding the best (most 'democratic') way to respond to the benefits of complex governance. Second, a Gramscian-influenced critique was developed, notably by Jonathan Davies. Third, Bevir and Rhodes (2012; Bevir, 2010, esp. Chapter 4) proposed an alternative reading of governance in a 'third wave' of governance shifts, theorising 'governance' as being constituted in the stories told (by political actors) about governing.

\section{Roskilde School, the Gramscian Critique and Governance as Practice}

The members of the 'Roskilde school' of Danish political theorists were among the earliest prescriptive proponents of the idea that market mechanisms could not accommodate the special characteristics of public policy - i.e. to define collective action for collective and politically accountable purposes. Yet they also argued that a 'return' to a hierarchical or rule-bound form of organisation was also undesirable.

This school of thought addressed itself to the challenges hinted at in the debates on the emergence of steering as the main role of policymaking. The increased social complexity of late modernity, with its individualised subjectivities, apparently identity-based and post-material politics, and the presumed decline of organised and class-based hierarchical society led to the need to generate new forms of citizenship and engagement with the collective organisation of social life (Bang, 2003; Kooiman, 2000, 2010). These social transformations were argued to place new challenges on 'the state' and the nature of government. What was required was something neither wholly state nor wholly private, the forging of new relationships across the public/private boundaries (cf Mayntz, 2004), something called 'governance networks'. Contrasting with the categorisation of policy networks organised in and around a centripetal state discussed earlier in this chapter, governance networks are conceptualised as resting on distributed power relations, in which state actors may, but need 
not, be dominant. Over time, the governance networks themselves contribute to the distribution of political power and resources. Organising policy and decision-making through governance networks would create a relatively open system of purposeful policymaking where policy actors are both autonomous and not hierarchically positioned in relation to one another:

[a] network of interdependent yet autonomous actors engaged in institutionalized processes of public governance based on negotiated interactions and joint decision making. (Sørensen and Torfing, 2009, p. 237)

For Sørensen, Torfing and colleagues (Sørensen, 2013; Sørensen and Torfing, 2007), the development of 'governance networks' in a specific setting should lead to the emergence of a new way of governing. 'Network governance' involves the autonomous self-organisation of policy actors, often from a diverse range of institutions (e.g. private, public, agency, third sector) to develop and co-ordinate policy agendas and ideas, and to promote more open and flexible participation in policy development, deliberation and delivery. In later work they do acknowledge that network governance is one way among others through which governing is done or public policy is made, but this makes their normative preference for 'network governance' as an empirically identifiable form of governance all the more striking (Sørensen and Torfing, 2009).

The networks of 'network governance' are inter-institutional. These networks overcome institutional and sectoral boundaries between policy domains, at least for the duration of the network and its purpose. Network governance conceptualises an empirical phenomenon where governing is primarily done through such self-organising networks, which function to achieve public purpose and goals without a hegemon or even pre-defined direction, and without contracts. Network governance is flexible and adaptable, so networks themselves can cross-over, form and re-form; they prioritise goal-oriented, informal ways of thinking and doing governance that rely on high levels of interpersonal trust.

Roskilde school scholars recognised that their conceptualisation of network governance, and claims about its emergence and characteristics in specific empirical settings poses questions of democratic deliberation, accountability and political choices over how governing might be done. For example, how do we decide to make policy on the basis of a market-based contract or through deliberation? Networks can only ever govern in 'the shadow of hierarchy' (Börzel, 2010; Heritier and Lehmkuhl, 2008) and we need systems of 'metagovernance' to choose how best to make policy in any one instance (see also the discussion in Jessop, 2003). Eventually, this perspective results in a rather conventional view of how to secure accountability (Sørensen and 
Torfing, 2018; Torfing, 2016). The state should keep oversight via conventional means of representative parliamentary party politics, but there should not be a return to state bureaucracies as the main way of developing policies.

Concerns with governing have also led to a valuable stream of work on the role of, and potential for, deliberative policymaking to re-enchant democratic decision-making (Elstub et al., 2016; Fischer, 2009). Yet there is a striking lack of attention to the limited and specific contexts within which a democratic ethics of governing and policymaking has been claimed and fought for in 'deliberative systems', or why. These recent theoretical reflections on deliberative decision-making lack engagement with the settings in which deliberation takes place: in particular states, places and times. To theorise how deliberation, participation and governing intersect in social and political change requires conceptual attention to how power, policy and decision-making are produced and shaped in practices and relative positions of political actors (Gottweis, 2003; Griggs et al., 2014; Wagenaar, 2011).

More sceptical views about the democratic possibilities of network governance, and with a significantly less sanguine view of 'metagovernance' came from British scholars, but there is also disagreement among them. Jonathan Davies (2011, 2012; Davies and Chorianopoulos, 2018) argues that 'network governance' is a misleading misnomer. Using examples from the UK, he argues that the state remains the most powerful actor in public policy and governing more broadly. The state sets the purpose, direction, resources and membership of public policy, and can start or shut down networks as well. Using the work of Antonio Gramsci, he argues that 'network governance' disguises the maintenance of state power through networks (for example, we might consider whether non-governmental organisations (NGOs) working on policy with local or national government are 'co-opted' into a policy agenda that they may not agree with). Davies also shows that in theories of network governance there is a relative lack of attention to the structural conditions of governance networks, and to questions of how power and authority are distributed and organised in 'network governance', notably in relation to the state (cf Davies, 2011).

Mark Bevir (Bevir, 2013; Bevir and Rhodes, 2010, 2012) is also sceptical about the normative claims of the Roskilde school. Originally through his work with Rod Rhodes, but also in his work on democratic governance, he argued that while networks are important as modes of governance, they are not only one among many but that 'network governance' is part of the third wave of governance (Bevir, 2010, pp. 65ff). More than this, 'network governance' is bad for democracy: it makes accountability blurred, privileges particular forms of expertise and experts, and de-politicises significant conflicts in policymaking (Bevir, 2010, Chapter 5; and pp. 214-220). It is also unrealistic, in his view, to see governance as anything other than what is practised by 
policymakers (rather than what they claim they want to do). This critique stems from Bevir's rather different theoretical position on governance. In their most extended discussion of governance as a theory, Bevir and Rhodes argue that it is the description of practices as 'governance' that brings it into being; 'governance' has no essence or objective existence. 'Governance' is used by social actors as a descriptor of phenomena that are understood as sharing 'family resemblances' (Bevir and Rhodes, 2010: 92-95) from the stories that policymakers tell about them. 'Governance is not a given set of characteristics. It is the stories people use to construct, convey and explain traditions, dilemmas, beliefs and practices.' (Bevir and Rhodes, 2010: 94).

This position offers an anti-foundationalist view of 'the state', as cultural practice. The state is neither system, institutions, nor assemblage. Social actors are only conditioned in their action by their own sedimented interpretations of how things are done ('traditions'). Stories and traditions matter more than institutions, positionality, power and political economy, which, in this strong interpretivist position, only exist as aspects of these actors' stories. This argument combined Rod Rhodes' ethnographic-type research on policymaking in Whitehall with Bevir's interest in anti-foundationalist theory. Its flaws also stem from these origins. Our account of governance also uses the concept of 'practices' (discussed in Chapter 2). However, our account differs in important ways from the claims of all three preceding theoretical approaches.

First, we reject the narrative of progression from simple states/governments to governance, and, indeed, its counterpart in broader theoretical explanations of the emergence of 'the state'. We reject the possibility of a unitary historical narrative, and instead develop a reading of the always empirically variable, but still structured, intersection of politics, power and statehood in governance. This then enables us to treat governing practices as both politically structured and as having material outcomes that affect socio-economic inequalities and the relational positions of social actors more widely. Governing practices are organised around, and reproduce, asymmetries of power and social inequality, in a 'regime' that neither ignores nor makes assumptions about the presence, absence or power of 'the state' in a hegemonic formation. This position also attends to the critiques of Rhodes' erasure of the profoundly context-dependent, elite, classed/gendered/ethnicised, and highly structured organisation of power in Whitehall in his ethnographic work on governance, from which he developed his later conceptual accounts of governance (see especially Kjær 2011). A truly social and political ethnography of governance must accommodate and make visible these patterns of power and their effects on the collective organisation of social life.

Second, we treat governing practices as comprising both meaning-making/ interpretation and political action. Processes of governing, and the positionality of actors, are indeed subject to interpretation about conditions of possibility for 
policy or political action. But they are also manifest in actions that have material effects on individual lives, relative social positions and collective experiences. Governing practices are also inscribed in the real objects and artefacts of government, like databases, forms, files, fines, ID cards, guns, flak jackets and walls. Such artefacts, material as well as digital, also contribute to how we physically or socially organise, order and manage populations, individuals and their social relationships. Governing practices link meaning-making and discourse together with action and with artefacts. When conceptualised and investigated creatively, systematically and carefully, it is through (regimes of) governing practices that we can reveal deeply unequal and barely visible relations of power in governance.

Third, and extending the contributions of policy studies and governance studies, we integrate into our approach an analysis of the consequences of policymaking. In our conceptualisation, governing practices include the purpose/ intent of policy. As result, we can analyse how such practices contribute to the production of socio-political order, whether this is by attempting to steer social subjects, by legitimising or producing particular processes and by producing or contesting the relational distribution of power and other resources. Rather than reifying policy as a product of policy processes, or governance as expressed in 'modes of governing', we interpret both policy and governance as dynamically related to the (re)production of social relations, including the distribution of power and authority in a specific setting.

\section{GOVERNANCE ANALYSIS}

At the beginning of this chapter, I suggested that in order to 'rescue' the usefulness of the idea of governance, there are three requirements that must be met.

First, any theoretical account of governance should be theoretically coherent and robust. This means that we need to move beyond description of 'types', 'modes' or 'waves' of governance into a theoretical account of what 'governance' is and how it matters. Theoretical coherence also requires that this account should be political: not technocratic, but enabling us to account for how governance is produced both through action by particular political actors, and through conditions of possibility for action that are structured and marked by power asymmetries. And this account should be social: historicised, seeing governing as inscribed in, and shaping, the formation and organisation of societies, while taking seriously the intent, purpose and form of 'policy' and governing.

Second, this account should facilitate a critical interrogation of how statehood, governing and policy are linked together, both in general and in specific contexts. Without such an interrogation, any account of governance easily lapses into assumptions about the existence, and preeminent role, of 'the state' 
shaping social relations. At the centre of a theoretical account of governance must be an interrogation of how statehood, and the authority to act as a state, are produced by the interactions and practices of social actors and with what implications for political and social inequalities over time. Both these requirements are addressed in our theoretical account of governance, discussed in detail in Chapter 2.

Third, our account should be analytically coherent, that is, applicable to the investigation of specific cases of 'governance' in a wide range of institutional and political settings. The translation of general theoretical claims into workable analytical framework is a fraught task, especially in light of the interpretivist approach adopted by many of our contributors. What is needed is a framework that is simple enough to manage the tension between workability and insight. We address these concerns in Chapter 3. We outline an analytical framework that enables us to analyse regimes of governing practices as constituted from specific relationships between structures, actors and processes. These relationships, and how they are revealed in governing practices, are our object of analysis. Evaluated in light of three contexts - socio-spatial, socio-economic and temporal - we are able to explore the socio-political ordering effects of these governing practices.

The theoretical account and analytical framework must not only 'work' in application to specific governing practices or regimes, but must also make sense of these specific cases in ways that illuminate wider theoretical concerns of governance analysis and/or the specific theoretical concerns of the setting. In Chapters 4 to 10 we discuss a range of examples exploring how governing is done in diverse empirical settings. These examples pay close attention to how governance analysis sheds light on the implications of policy for how governing in particular settings shapes political and social inequalities, in keeping with the theoretical account we propose.

In Part II, Chapters 4 (Hannah Durrant), 5 (Regine Paul), 6 (Fiona Morgan) and 7 (Jenny Harlock), we examine the workings of governing practices centred around the production of particular states and statehoods in policy, states that are also fully imbricated in the (re)production of unequal social relations. Durrant addresses the development of 'skills policy' in England, and shows how three types of political actor engaged with, re-worked and challenged this policy, while also reproducing it. Paul examines how state actors in France, Germany and the UK selectively engaged structural conditions to develop differentially selective labour migration policies. Morgan forensically investigates a complex environment that cuts across three separate domains of state policymaking to structurally position informal carers in contradictory and socially unprotected positions. Harlock shows how local authority actors and third sector organisations negotiated their relationship under the shadow of (partial, uneven) contractualisation of public services and, in doing so, jointly 
produced the structural conditions under which that contractualisation was practised and changed the relationship of state and third sector.

In Part III, Chapters 8 (Michelle Farr), 9 (Sarah Morgan-Trimmer) and 10 (Hester Kan) examine how governing practices are produced by social actors whose positioning in governance is both highly structured and unequal, but also contestable, flexible, and contingent on their actions and their interpretive understanding of their positions. Farr examines two concrete processes of service co-production, in health services and a local authority. She explains how these processes generated new intersubjective understandings among policy actors, professional staff and service users, but also reproduced and disguised wider structural conditions of their participation. Morgan-Trimmer, focusing on those citizens 'at the margins' of the state, explains how citizens re-made their positions from feeling ignored to being a target of governance, pursued their own goals, and strategically selected their engagement with participatory governance in ways that protected their needs. Kan explores how policy professionals engaged in two European Union (EU) networks. She shows that they were always and at the same time: managing and pursuing their policy agendas in both the domestic and the Europeanised environments, positioning themselves politically in relation to other actors in the network and shaping the structural context within which the network operated.

Before introducing this array of empirical case examples, we must explain in more detail the theoretical basis for our definition of governance as a regime of governing practices that produce socio-political orders over time: Chapter 2.

\section{REFERENCES}

Aitken, R., 2010. Ambiguous incorporations: microfinance and global governmentality. Global Networks 10, 233-243.

Ansell, C., Torfing, J., 2016. Introduction: theories of governance, in: Ansell, C., Torfing, J. (Eds.), Handbook on Theories of Governance. Oxford University Press, Oxford, pp. 1-21.

Bachrach, P., Baratz, M.S., 1962. Two faces of power. The American Political Science Review 56 (4), 947-952.

Bakker, I., 2008. Neo-liberal governance and the reprivatization of social reproduction: social provisioning and shifting gender orders, in: Bakker, I., Gill, S. (Eds.), Power, Reproduction and Social Reproduction. Palgrave, London, pp. 66-82.

Bang, H., 2003. A new ruler meeting a new citizen: culture governance and everyday making, in: Bang, H. (Ed.), Governance as Political and Social Communication. Manchester University Press, Manchester, pp. 241-266.

Baumgartner, F.R., Jones, B.D., 2010[1993]. Agendas and Instability in American Politics. University of Chicago Press, Chicago. 
Beermann, J., 2017. Urban Cooperation and Climate Governance: How German and Indian Cities Join Forces to Tackle Climate Change. Springer VS, Wiesbaden.

Berry, C., Gabay, C., 2009. Transnational political action and 'global civil society' in practice: the case of Oxfam. Global Networks 9, 339-358.

Bevir, M., 2003. A decentred theory of governance, in: Bang, H. (Ed.), Governance as Political and Social Communication. Manchester University Press, Manchester, pp. 200-221.

Bevir, M., 2010. Democratic Governance. Princeton University Press, Princeton, NJ.

Bevir, M., 2013. A Theory of Governance. University of California Press, Berkeley.

Bevir, M., Rhodes, R.A.W., 2010. The State as Cultural Practice. Oxford University Press, Oxford.

Bevir, M., Rhodes, R.A.W., 2012. Interpretivism and the analysis of traditions and practices. Critical Policy Studies 6, 201-208.

Birch, A., 1984. Overload, ungovernability and delegitimation: the theories and the British case. British Journal of Political Science 14, 135-160.

Bode, I., 2006. Disorganized welfare mixes: voluntary agencies and new governance regimes in Western Europe. Journal of European Social Policy $16,346-359$.

Börzel, T., 2010. European governance: negotiation and competition in the shadow of hierarchy. Journal of Common Market Studies 48, 191-219.

Botzem, S., Hofmann, J., 2010. Transnational governance spirals: the transformation of rule-making authority in Internet regulation and corporate financial reporting. Critical Policy Studies 4, 18-37.

Bridge, G., Wood, A., 2005. Geographies of knowledge, practices of globalization: learning from the oil exploration and production industry. Area 37, 199-208.

Broad, R., 2006. Research, knowledge, and the art of 'paradigm maintenance': the World Bank's Development Economics Vice-Presidency (DEC). Review of International Political Economy 13, 387-419.

Cairney, P., Jones, M.D., 2016. Kingdon's Multiple Streams Approach: What Is the Empirical Impact of this Universal Theory? Policy Studies Journal 44, 37-59.

Chesterman, S., Fisher, A., 2009. Private Security, Public Order: the outsourcing of public services and its limits. Oxford University Press, Oxford.

Cohen, M.D., et al., 1972. A garbage can model of organizational choice. Administrative Science Quarterly 17, 1-25.

Davies, J., 2011. Challenging Governance Theory: From Networks to Hegemony. Policy Press, Bristol. 
Davies, J., 2012. Network governance theory: a Gramscian critique. Environment and Planning A 44, 2687-2704.

Davies, J., Chorianopoulos, I., 2018. Governance: mature paradigm or chicken soup for European public management? Critical Policy Studies 12, 360-366.

de Sousa Santos, B., 2012. Public sphere and epistemologies of the South. Africa Development 37, 43-67.

Elgert, L., 2010. Politicizing sustainable development: the co-production of globalized evidence-based policy. Critical Policy Studies 3, 375-390.

Elstub, S., et al., 2016. The fourth generation of deliberative democracy. Critical Policy Studies 10, 139-151.

Escobar, A., 2001. Culture sits in places: reflections on globalism and subaltern strategies of localization. Political Geography 20, 139-174.

Fischer, F., 2009. Democracy and Expertise. Oxford University Press, Oxford.

Foucault, M., 2007. Security. Territory. Population. Palgrave Macmillan, Basingstoke.

Gill, S., Cutler, A.C., 2014. New Constitutionalism and World Order. Cambridge University Press, Cambridge.

Gottweis, H., 2003. Theoretical strategies of poststructuralist policy analysis: towards an analytics of government, in: Hajer, M.A., Wagenaar, H. (Eds.), Deliberative Policy Analysis: Understanding Governance in the Network Society. Cambridge University Press, Cambridge, pp. 247-264.

Griggs, S., et al., 2014. Practices of Freedom. Decentred Governance, Conflict and Democratic Participation. Cambridge University Press, Cambridge.

Gupta, A., 1995. Blurred boundaries: the discourse of corruption, the culture of politics, and the imagined state. American Ethnologist 22, 375-402.

Heritier, A., Lehmkuhl, D., 2008. The shadow of hierarchy and new modes of governance. Journal of Public Policy 28, 1-17.

Jessop, B., 1990. State Theory: Putting the Capitalist State in its Place. Polity, Cambridge.

Jessop, B., 1999. The changing governance of welfare: Recent trends in its primary functions, scale, and modes of coordination. Social Policy and Administration 33, 348-359.

Jessop, B., 2002. The Future of the Capitalist State. Polity, Cambridge.

Jessop, B., 2003. Governance and meta-governance: on reflexivity, requisiste variety and requisite irony, in: Bang, H. (Ed.), Governance as Social and Political Communication. Manchester University Press, Manchester, pp. 101-116.

Kingdon, J., 1984. Agendas, Alternatives and Public Policies. Little Brown, Boston.

Kjær, A.M., 2011. Rhodes' contribution to governance theory: praise, criticism and the future governance debate. Public Administration 89, 101-114.

Kooiman, J., 1993. Modern Governance. Sage, London. 
Kooiman, J., 2000. Societal governance: levels, models and order of social-political interaction, in: Pierre, J. (Ed.), Debating Governance. Oxford University Press, Oxford, pp. 138-166.

Kooiman, J., 2003. Governing as Governance. Sage, London.

Kooiman, J., 2010. Governance and governability, in: Osborne, S.P. (Ed.), The New Public Governance. Emerging Perspectives on the Theory and Practice of Public Governance. Routledge, London, pp. 72-86.

Kothari, U., 2005. Authority and expertise: The professionalisation of international development and the ordering of dissent. Antipode 37, 425-446.

Larner, W., Laurie, N., 2010. Travelling technocrats, embodied knowledges: globalising privatisation in telecoms and water. Geoforum 41, 218-226.

Liese, A., Beisheim, M., 2011. Transnational public-private partnerships and the provision of collective goods in developing countries, in: Risse, T. (Ed.), Governance without a State? Columbia University Press, Columbia, pp. 115-143.

Lindblom, C., 1979. Still muddling, not yet through. Public Administration Review 39, 517-526.

Lipsky, M., 2010. Street-level bureaucracy: Dilemmas of the individual in public services (expanded ed.). Russell Sage Foundation, New York.

Mayntz, R., 2004. 'Governance im modernen Staat', in: Benz, A. (Ed.), Governance - Regieren in komplexen Regelsystemen. Eine Einführung. VS Verlag für Sozialwissenschaften, Wiesbaden.

Mayntz, R., 2016. Steering, in: Ansell, C., Torfing, J. (Eds.), Handbook on Theories of Governance. Oxford University Press, Oxford, pp. 259-266.

Mignolo, W., 2007. Delinking. Cultural Studies 21, 449-514.

Mignolo, W., 2010. Cosmopolitanism and the de-colonial option. Studies in Philosophy and Education 29, 111-127.

Mignolo, W., 2011. Geopolitics of sensing and knowing: on (de)coloniality, border thinking and epistemic disobedience. Postcolonial Studies 14, 273-283.

Mörth, U., 2009. The market turn in EU governance - the emergence of public-private collaboration. Governance 22, 99-120.

Newman, J., 2004. Modernizing the state: a new form of governance?, in: Lewis, J., Surender, R. (Eds.), Welfare State Change: Towards a Third Way? Oxford University Press, Oxford, pp. 69-88.

Newman, J., 2005. Remaking Governance: Peoples, Politics and the Public Sphere. Policy Press, Bristol.

Newman, J., Clarke, J., 2009. Publics, Politics and Power: Remaking the Public in Public Services. Sage, London.

Osborne, S.P., 2010. The New Public Governance. Emerging Perspectives on the Theory and Practice of Public Governance. Routledge, London. 
Ponte, S., Cheyns, E., 2013. Voluntary standards, expert knowledge and the governance of sustainability networks. Global Networks 13, 459-477.

Prince, R., 2012. Policy transfer, consultants and the geographies of governance. Progress in Human Geography 36, 188-203.

Raffaele, R., 2017. Partnerships in International Policy-making: Civil Society and Public Institutions in European and Global Affairs. Palgrave Macmillan, London.

Rhodes, R.A.W., 1996. The new governance: Governing without government. Political Studies 44, 652-667.

Rhodes, R.A.W., 2000. Governance and public administration, in: Pierre, J. (Ed.), Debating Governance. Oxford University Press, Oxford, pp. 54-90.

Rhodes, R.A.W., 2012. Three waves of governance, in: Levi-Faur, D. (Ed.), Oxford Handbook of Governance. Oxford University Press, Oxford, pp. 33-48.

Rhodes, R.A.W., Marsh, D., 1992a. New directions in the study of policy networks. Journal of European Political Research 21, 181-205.

Rhodes, R.A.W., Marsh, D., 1992b. Policy Networks in British Government. Clarendon Press, Oxford.

Rosenau, J., 2000. Change, complexity and governance in globalizing space: Authority, Steering and Democracy, in: Pierre, J. (Ed.), Debating Governance. Oxford University Press, Oxford, pp. 167-200.

Sabatier, P.A., Jenkins-Smith, H.C., 1993. Policy Change and Learning: An Advocacy Coalition Approach. Westview Press, Boulder CO.

Sabel, C.F., Zeitlin, J., 2010. Experimentalist Governance in the European Union: Towards a New Architecture. Oxford University Press, Oxford.

Saint-Martin, D., 1998. The new managerialism and the policy influence of consultants in government: An historical-institutionalist analysis of Britain, Canada and France. Governance 11, 319-356.

Sassen, S., 1996. Losing Control? Sovereignty in an Age of Globalization. Columbia University Press, New York; Chichester.

Schuppert, G.F., 2011. Law without a state? A 'new interplay' between state and nonstate actors in governance by rule making, in: Risse, T. (Ed.), Governance without a State? Columbia University Press, Columbia, pp. 65-88.

Seabrooke, L., Tsingou, E., 2009. Revolving Doors and Linked Ecologies in the World Economy: Policy Locations and the Practice of International Financial Reform, CSGR Working Papers. University of Warwick.

Shaffer, G., 2013. Transnational legal ordering and state change, in: Shaffer, G. (Ed.), Transnational Legal Ordering and State Change. Cambridge University Press, Cambridge, pp. 1-22.

Smith, M.P., 1993. Pressure, Power and Policy: State Autonomy and Policy Networks in Britain and the United States. Harvester Wheatsheaf, London. 
Sørensen, E., 2013. Institutionalizing interactive governance for democracy. Critical Policy Studies 7, 72-86.

Sørensen, E., Torfing, J., 2007. Theoretical approaches to meta-governance, in: Sørensen, E., Torfing, J. (Eds.), Theories of Democratic Network Governance. Palgrave Macmillan, Basingstoke.

Sørensen, E., Torfing, J., 2009. Making governance networks effective and democratic through metagovernance. Public Administration 87, 234-258.

Sørensen, E., Torfing, J., 2018. Governance on a bumpy road from enfant terrible to mature paradigm. Critical Policy Studies 12, 350-359.

Stattman, S.L., Gupta, A., 2015. Negotiating authority in global biofuel governance: Brazil and the EU in the WTO. Global Environmental Politics 15, 41-59.

Torfing, J., 2016. Metagovernance, in: Ansell, C., Torfing, J. (Eds.), Handbook on Theories of Governance. Oxford University Press, Oxford, pp. 525-537.

Vaughan, S., Rafanell, I., 2012. Interaction, consensus and unpredictability in development policy 'transfer' and practice. Critical Policy Studies 6, 66-84.

Wagenaar, H., 2011. Meaning in Action: Interpretation and Dialogue in Policy Analysis. M.E. Sharpe, Inc, New York.

Wedel, J., 1998. Collision and Collusion: The Strange Case of Western Aid to Eastern Europe, 1989-1998. Macmillan, Basingstoke.

Weible, C.M., Cairney, P., 2018. Practical lessons from policy theories. Policy \& Politics 46, 183-197. 